\title{
Maize Plants Infestation by Fusarium spp. and Deoxynivalenol in Genetically Modified Corn Hybrid and Traditional Maize Cultivars
}

\author{
MAREK SELWET* \\ Poznań University of Life Sciences, Department of Environmental Microbiology \\ Poznań, Poland
}

Received 7 December 2010, revised 24 August 2011, accepted 25 August 2011

\begin{abstract}
The objective of the performed investigations was to isolate pathogenic fungi from contaminated maize cobs, to assess the appearance of maize cob fusariosis and to determine grain contamination with deoxynivalenol in the cultivation of genetically modified maize containing a gene resistance against European corn borer (Ostrinia nubilalis $\mathrm{Hbn}$ ) as well as selected non-modified cultivars. The plant material comprised the following genetically modified maize cultivar: DKC 3421 YG (MON 810) and non-modified cultivars obtained from Smolice Plant Breeding Ltd., IHAR Group: Junak (FAO 210-220), Prosna (FAO 220), SMH (FAO 230), Baca (FAO 220). Prior to harvesting, the occurrence of maize cob fusariosis was determined in the $89(\mathrm{BBCH})$ developmental ripening stage. Microbiological assessment was carried out on grains selected from cobs characterized by various pathological symptoms. In 2008, a total of 133 isolates was obtained from the examined samples of infected maize plants, of which 51 isolates were species-identified, while in 2009, the total of 123 isolates were determined, of which 63 were species-identified. In both experimental years, the majority of isolates contained fungi from the Fusarium genus. The performed analysis of mean levels of cob contamination by fusarioses revealed that DKC 3421 YG (MON 810) and SMH (FAO 230) cultivars showed the smallest levels of contamination as well as the lowest percent of cob contamination per plant, while Junak (FAO 210-220) and Baca (FAO 220) cultivars were characterized by the highest degree of contamination. The lowest deoxynivalenol concentrations were determined in years 2008 and 2009 in the case of the DKC 3421 YG (MON 810) cultivar, whereas Prosna (FAO 220) cultivar was characterized by the highest deoxynivalenol concentration.
\end{abstract}

Ke y words: Fusarium spp., deoxynivalenol, maize, GMO

\section{Introduction}

Pathogenic fungi from the Fusarium genus causing foot-rot and cob fusariosis pose a very serious threat to maize cultivations in Poland (Tekiela and Gabarkiewicz, 2007; Selwet, 2009). Fusarioses are caused, primarily, by Fusarium culmorum, Fusarium avenaceum, Fusarium graminearum, Fusarium oxysporum (Fiedorow et al., 2001). Cob fusariosis causes mild crop losses; nevertheless, it results in deterioration of grain quality due to contamination with mycotoxins, e.g. deoxynivalenol (Lisowicz and Tekiela, 2004). Mycotoxins may cause a number of diseases both in people and animals, including allergies, hormonal disorders, and neoplasms (Tekiela, 2008). Mean yield losses due to the foot rot vary from 10 to $35 \%$ (Sulewska et al., 2006). Among important factors leading to the infection of maize with Fusarium is feeding of various pests, primarily, European corn borer (Ostrinia nubilalis $\mathrm{Hbn}$ ) as this facilitates tissue penetration by the pathogen and damages plants (Tekiela et al., 2005; Selwet, 2009). One of the methods reducing the infestation of maize by pathogens could be cultivation of resistant varieties genetically modified by a gene resistant to the European corn borer (Tekiela and Gabarkiewicz, 2007; Selwet, 2009). However, there are serious reservations concerning cultivation of genetically modified (GM) cultivars due to their possible negative influence on the environment. Many researchers reported increased mortality of butterflies and ladybirds following ingestion of toxic protein from GM maize (Hilbeck and Schmidt, 2006) or impairment of spatial orientation in bees (Ramirez-Romero et al., 2008). Transfer of traits resulting from the applied genetic modification between totally alien organisms may also turn out to be a serious threat (Duggan et al., 2002). Although for the above-mentioned reasons, cultivation of genetically modified cultivars remains controversial, the area under MON 810 maize cultivation in Poland increased from approximately 300 ha in 2007 to 3000 ha in 2008 .

* Corresponding author: M. Selwet, Poznań University of Life sciences, Department of Environmental Microbiology, Szydłowska 50, 60-656 Poznań, Poland; e-mail: mselwet@jay.au.poznan.pl 
The presented paper is a continuation of a research project conducted in 2006-2007. It involved isolation of pathogen fungi from infected cobs, assessment of the appearance of maize cob fusariosis and determination of grain infection by deoxynivalenol in cultivations of GM maize containing the gene of resistance against the European corn borer (Ostrinia nubilalis Hbn) as well as selected non-modified cultivars.

The experiment was established in Nowa Wieś Kącka in Kąty Wrocławskie commune, of Wrocław District in the Lower Silesia Voivodeship (5102’ N, 1646’ E). The village is situated in the Silesian Lowland, in the eastern part of the Wrocław Plain (132 m a.s.l). It is situated centrally between Środa Upland and Grodkowo Plain. Glacial and glacial-fluvial deposits are covered by loess on which brown soils and chernozems were formed.

\section{Experimental}

\section{Material and Methods}

Plant material. The experimental plant material comprised a GM maize cultivar: DKC 3421 YG (MON 810) (containing a Bt gene of resistance against the European corn borer Ostrinia nubilalis $\mathrm{Hbn}$ ) as well as nonmodified cultivars from the Smolice Plant Breeding Ltd, IHAR Group: Junak (FAO 210-220), Prosna (FAO 220), SMH (FAO 230), and Baca (FAO 220). Investigations were carried out in 2008-2009.

Prior to the harvest of maize conducted at the developmental phase $89(\mathrm{BBCH})$, the occurrence of maize cob fusariosis was determined in accordance with the methodology given by Tekiela and Gabarkiewicz (2007). One hundred plants (20 plants from 5 replicates) were analysed using for this purpose a five-score scale (Kwaśna et al., 1991), (Table I).

Table I

Scale used for evaluation of cobs infestation by Fusarium genus

\begin{tabular}{|c|l|}
\hline Degree & \multicolumn{1}{|c|}{ Description } \\
\hline 1 & Very small (1-6 grains, $2 \%)$ \\
\hline 2 & Small (7-30 grains, $3-10 \%)$ \\
\hline 3 & Medium (1/3 of cob, 11-30\%) \\
\hline 4 & Large (1/2 of cob, $31-50 \%)$ \\
\hline 5 & Very large ( $>1 / 2$ of cob, $51-100 \%)$ \\
\hline
\end{tabular}

Microbiological evaluation was performed on kernels obtained from cobs exhibiting different types of pathogenic symptoms. The employed procedures followed methodology developed by Rataj-Guranowaska and Frąckowiak (2006).

Media and cultivation conditions. Tissue fragments (collected from the border between healthy and sick tissues situated in different places of the overground shoot) were surface disinfected in $15 \%$ sodium hypochlorite for the period of 45 seconds. Next, samples were rinsed three times in sterile distilled water. Disinfected slices were placed on Petri dishes with the Potato Dextrose Agar (PDA, DIFCO) of $\mathrm{pH}$ 4.5-5.0 and incubated for 5-7 days at the temperature of $24^{\circ} \mathrm{C}$. The developed fungal colonies were inoculated onto the Potato Dextrose Agar (PDA, DIFCO) and, in the case of Fusarium, also on Saltwater Nutrient Agar (SNA). Following incubation, mycelium was subjected to macroscopic analysis (colour and structure of mycelium). Microscopic descriptions of fungi were prepared 5 and 10 days from the moment of isolate inoculation. The performed microscopic analysis involved cultures grown on the Saltwater Nutrient Agar (SNA) and comprised determination of the size of conidial spores, conidiogenesis and the type of fialide as well as the presence of microconides and chlamidospores. Identification was carried out on the basis of Both's (1971) and Burgess's et al. (1988) keys.

Deoxynivalenol content. Deoxynivalenol was determined according to methodology given by WiśniewskaDmytrow and Kozak (2006). Deoxynivalenol was extracted from the experimental plant material with water in the presence of polyethylene glycol. The extract was then purified on the immunological affinity column (DONtest ${ }^{\mathrm{TM}}$ HPLC, of VICAM Company) containing antibodies specific for this mycotoxin. Deoxynivalenol was eluted from the column with $1.5 \mathrm{ml}$ methyl alcohol of HPLC purity with the speed of 1 drop min $^{-1}$ into a test tube of $5 \mathrm{ml}$ volume. The eluate was evaporated dry in a stream of nitrogen at the temperature of $40^{\circ} \mathrm{C}$. The residue was dissolved in $0.5 \mathrm{ml}$ of standard mobile phase $\left(0.2 \mu \mathrm{g} \mathrm{ml}^{-1}\right)$ and mixed on a Vortex. After thickening, the eluent was determined qualitatively and quantitatively with the assistance of liquid chromatography (LC) method using the UV-VIS detector.

Meteorological conditions. Values of air temperature and rainfall were obtained from the Institute of Meteorology and Water Management (IM\&WM) in Wrocław.

Statistics. The obtained results were subjected to statistical analysis employing the glm procedure of the SAS package (1998) and the significance of differences was verified by the Duncan method.

\section{Results}

Meteorological conditions prevailing during the experimental years as well as the extent of cob damage by the European corn borer could have favoured the development of fungi from the Fusarium genus (Tables II-III). 
Table II

Fusarium infestation on corn cobs in Nowa Wieś Kącka

\begin{tabular}{|cc|c|c|c|c|}
\hline \multirow{2}{*}{ No Cultivars } & \multicolumn{2}{|c|}{ Average degree of cob infestation in years } & \multicolumn{2}{c|}{$\%$ of cob infestation in years } \\
\cline { 3 - 6 } & & $1^{\text {st }}$ year & $2^{\text {nd }}$ year & $1^{\text {st }}$ year & $2^{\text {nd }}$ year \\
\hline 1 & DKC 3421 YG (MON 810) & $0.07 \mathrm{a}$ & $0.10 \mathrm{a}$ & $1.60 \mathrm{a}$ & $1.73 \mathrm{a}$ \\
\hline 2 & Junak (FAO 210-220) & $0.49 \mathrm{~b}$ & $0.52 \mathrm{~b}$ & $20.01 \mathrm{~b}$ & $25.61 \mathrm{~b}$ \\
\hline 3 & Prosna (FAO 220) & $0.40 \mathrm{~b}$ & $0.41 \mathrm{~b}$ & $6.10 \mathrm{c}$ & $6.21 \mathrm{c}$ \\
\hline 4 & SMH (FAO 230) & $0.21 \mathrm{c}$ & $0.23 \mathrm{c}$ & $2.91 \mathrm{~d}$ & $2.22 \mathrm{~d}$ \\
\hline 5 & Baca (FAO 220) & $0.66 \mathrm{~d}$ & $0.72 \mathrm{~d}$ & $17.21 \mathrm{~b}$ & $18.02 \mathrm{~b}$ \\
\hline
\end{tabular}

a, b c c d - means in columns designated with the same letters do not differ significantly at the level of $\mathrm{P}<0.05$

Table III

Monthly average air temperatures and atmospheric precipitation

\begin{tabular}{|l|c|c|c|c|c|c|c|c|c|c|c|c|c|}
\hline \multicolumn{1}{|c|}{ Years } & I & II & III & IV & V & VI & VII & VIII & IX & X & XI & XII \\
\hline \multicolumn{10}{|c|}{ Air temperatures in ${ }^{\circ} \mathrm{C}$} \\
\hline $1971-2000$ & -0.9 & 0.2 & 3.9 & 8.2 & 13.5 & 16.3 & 18,1 & 17.8 & 13.6 & 8.9 & 3.6 & 0.7 \\
\hline 2008 & 2.2 & 3.1 & 4.2 & 8.5 & 14.3 & 18.2 & 19.4 & 18.0 & 13.1 & 9.0 & 6.2 & 1.5 \\
\hline 2009 & -3.0 & 0.1 & 4.1 & 12.1 & 14.4 & 15.2 & 19.2 & 19.0 & 15.1 & 7.3 & 6.1 & -1.1 \\
\hline \multicolumn{10}{|c|}{ Total precipitation in mm } & & \multicolumn{7}{|c|}{5} \\
\hline $1971-2000$ & 28 & 24 & 30 & 37 & 57 & 79 & 91 & 64 & 51 & 38 & 37 & 34 \\
\hline 2008 & 50 & 20 & 43 & 75 & 42 & 27 & 54 & 76 & 25 & 52 & 25 & 23 \\
\hline 2009 & 32 & 51 & 53 & 11 & 65 & 153 & 154 & 53 & 20 & 61 & 31 & 43 \\
\hline
\end{tabular}

In 2008, a total of 133 isolates were obtained from all the examined samples of infected plants, of which 51 were identified with regard to species, whereas in 2009, a total of 123 isolates were determined, of which 63 were identified with regard to species. In both experimental years, fungi from the Fusarium sp. genus constituted the majority of the obtained isolates.

In addition, high proportions of black fungi from the Alernaria alternata species were also determined in our investigations. Moreover, fungi from the Trichoderma, Phoma Mucor genus and Cladosporium cladosporoides were also identified (Tabele IV).

Table IV

Number of fungal isolates obtained from maize

\begin{tabular}{|l|c|c|}
\hline \multicolumn{1}{|c|}{ Species } & $\begin{array}{c}\text { No isolates } \\
1^{\text {st }} \text { year } \\
10\end{array}$ & $\begin{array}{c}\text { No isolates } \\
2^{\text {nd }} \text { year } \\
\text { Fusarium oxysporum }\end{array}$ \\
\hline Fusarium graminearum & 17 & 12 \\
\hline Fusarium culmorum & 5 & 7 \\
\hline Fusarium avenaceum & 6 & 8 \\
\hline Alternaria alternata & 10 & 15 \\
\hline Cladosporium cladosporoides & 3 & 3 \\
\hline Trichoderma sp. & 5 & 3 \\
\hline Phoma sp. & 3 & 3 \\
\hline Mucor sp. & 3 & 2 \\
\hline Other fungi, nonsporulating fungi & 20 & 52 \\
\hline
\end{tabular}

When analysing the mean degree of cob infection with fusarioses, it was found that DKC $3421 \mathrm{YG}$ (MON 810) and SMH (FAO 230) cultivars exhibited the lowest degree of infestation as well as the lowest percent of infected cobs on a plant. On the other hand, Junak (FAO 210-220) and Baca (FAO 220) cultivars were found to have been infected most severely (Table II).

Due to strong infestation of maize by pathogenic fungi from the Fusarium genus, the content of deoxynivalenol in the examined samples was determined. The lowest deoxynivalenol concentrations were determined in years 2008 and 2009 in the case of the DKC 3421 YG (MON 810) cultivar and they amounted to $52 \mathrm{ppb}$ and $56 \mathrm{ppb}$, respectively, whereas the highest ones (244 ppb and $261 \mathrm{ppb}$, respectively) were found in the Prosna (FAO 220) cultivar. Deoxynivalenol concentrations in individual maize cultivars are shown in Table V.

Table V

Deoxynivalenol content in corn grain (ppb)

\begin{tabular}{|l|c|c|}
\hline \multicolumn{1}{|c|}{ Cultivars } & $1^{\text {st }}$ year & $2^{\text {nd }}$ year \\
\hline DKC 3421 YG (MON 810) & $41 \mathrm{a}$ & $32 \mathrm{a}$ \\
\hline Junak (FAO 210-220) & $213 \mathrm{~b}$ & $201 \mathrm{~b}$ \\
\hline Prosna (FAO 220) & $254 \mathrm{c}$ & $243 \mathrm{c}$ \\
\hline SMH (FAO 230) & $198 \mathrm{~b}$ & $186 \mathrm{~b}$ \\
\hline Baca (FAO 220) & $201 \mathrm{~b}$ & $199 \mathrm{~b}$ \\
\hline
\end{tabular}

a, b, c, - means in columns designated with the same letters do not differ significantly at the level of $\mathrm{P}<0.05$ 


\section{Discussion}

The obtained results indicated the most severe maize infestation with fungi from the Fusarium genus. In 2008, Fusarium graminearum species constituted the highest quantity of isolates (17 isolates). According to Boreski (2001), this species is characteristic for this period of vegetation $(89 \mathrm{BBCH})$ and infects, primarily, towards the end of maize vegetation. Also Fusarium oxysporum (a species rarely determined on maize plants at the phase of full kernel maturity) with its considerable number of isolates (10) deserves attention as its high intensity of development according to Kwaśna et al. (1991) and Fiedorow et al. (2001), coincides with maize emergence and may lead to seedling root-rot in plants. The smallest numbers of isolates were determined for Fusarium culmorum (5) and Fusarium avenaceum (6) species which, according to Rataj-Guranowska (2006), infect maize plants mainly during 33-39 (BBCH) phase. In 2009, the greatest numbers of determined isolates were as follows: Fusarium graminearum (19 isolates), Fusarium oxysporum (12), Fusarium avenaceum (8) and Fusarium culmorum (7). High quantities of Fusarium graminearum isolates observed during the $89 \mathrm{BBCH}$ phase of maize development corroborates literature data (Borecki, 2001). In years 2008 and 2009 high numbers of Alternaria alternata isolates were determined. High quantities of this species in maize were also reported by Rataj-Guranowska and Frąckowiak (2006) as well as Selwet (2009).

Concentrations of deoxynivalenol in the examined cultivars varied. In the case of the GMO DKC 3421 YG (MON 810) cultivar, low concentrations of mycotoxins were found in comparison with the non-modified cultivars which corroborated findings by Tekiela and Gabarkiewicz (2007) as well as Selwet (2009) who also reported in the GMO DKC 3421 YG maize cultivar the lowest concentrations of deoxynivalenol in comparison with non-modified cultivars. These results confirm lower sensitivity of the GM cultivar to the presence of secondary metabolites of mould fungi in comparison with non-modified cultivars (Munkvold and Desjardins 1997).

Tekiela and Gabarkiewicz (2007) maintain that in Poland no monitoring of the content of mycotoxins in maize grain is conducted. It can only be assumed on the basis of partial research that, depending on the intensity of occurrence of the European corn borer, the degree of plant infestation with Fusarium genus and meteorological conditions, up to $30 \%$ of harvested grain may contain mycotoxins in quantities exceeding acceptable standards. Higher levels of maize infestation with Fusarium genus may also be due to delayed harvest (Sulewska et al., 2006).
At the present time, the content of mycotoxins in maize grain is regulated by the $\mathrm{EU}$ instruction No. $1126 / 2007$ of the $28^{\text {th }}$ September 2007 which changed the earlier EU regulation No. 1881/2006. The above regulation allows the highest allowable level of deoxynivalenol as of the $1^{\text {st }}$ October 2007 at $1750 \mathrm{ppb}$ (Tekiela 2008).

Recapitulating the obtained results, the following conclusions can be drawn. Pathogenic fungi from the Fusarium genus turned out to be the most serious threat for maize cultivated in years 2008 and 2009 in the area of Kąty Wrocławskie commune. The most frequently isolated species were Fusarium graminearum and Fusarium oxysporum. Maize cob fusariosis was more intense in non-modified cultivars. The obtained results confirmed literature data that in order to limit the content of mycotoxins in maize grain, cultivation of genetically modified cultivars may be a feasible alternative.

\section{Literature}

Booth C. 1971. The Genus Fusarium. Commonwealth Mycological Institute, Kew, Surrey, England.

Borecki A. 2001. Science on plant diseases (in Polish). PWRiL, Warszawa.

Burgess L.W., C.M. Liddel and B.A. Summerell. 1988. Laboratory Manual for Fusarium Research. Fusarium Research Laboratory $2^{\text {nd }}$ ed. Department of Plant Pathology and Agricultural Entomology, The University of Sydney, Sydney.

Duggan C., J. Gannon and W.A. Walker. 2002. Protective nutrients and functional foods for the gastrointestinal tract. Am. J. Clin. Nutr. 75: 789-808.

Fiedorow Z., B. Gołębniak and Z. Weber. 2001. Diseases of agricultural plants (In Polish). Wyd. AR, Poznań.

Hilbeck A. and J.E.U. Schmidt. 2006. Another View on Bt Proteins - How Specific are They and What Else Might They Do? Biopestic. Int. 2: 1-50.

Kwaśna H., J. Chełkowski and P. Zajkowski. 1991. Polish flora - Mycota (In Polish) T. XXII. Polish Academy of Sciences, WarszawaKraków.

Lisowicz F. and A. Tekiela. 2004. Pests and diseases of mazie (In Polish), pp. 52-64. In: Dubas A. (eds) $3^{\text {rd }}$ ed. Technology production of maize Wieś Jutra, Warszawa.

Munkvold G.P. and A.E. Desjardins. 1997. Fumonisins in maize: can we reduce their occurrence. Plant Dis. 81: 556-565.

Rataj-Guranowska M. 2006. Disease symptoms of maize causes by Fusarium (In Polish) pp. 35. In: „Kompendium Symptomów Chorób Roślin oraz Morfologii ich Sprawców” M. Rataj-Guranowska (eds). Bogucki Wyd. Nauk. Poznań.

Rataj-Guranowska M. and M. Frąckowiak. 2006. Fungi pathogenic to maize from several locations of Wielkopolska and Kobierzyce area in 2004 (In Polish). Prog. Plant Protection 46: 723-725.

Ramirez-Romero R., N. Desneux, Decourtye A., A. Chaffiol and M.H. Pham-Delegue. 2008. Does Cry 1 Ab protein affect learning performances of the honey bee Apis mellifera L. (Hymenoptera, Apidae)? Ecotoxicol. Environ. Safety 70: 327-333.

SAS. 1998. User's Guide: Statistics, Version $7^{\text {nd }}$ ed., SAS Inst Inc Cary, NC. 
Selwet M. 2009. Pathogenic fungi and deoxynivalenol contamination in grain of genetically modified corn hybrid and traditional maize cultivars (In Polish). Ekologia i Technika 6: 276-280.

Sulewska H., W. Koziara and G. Ptaszyńska. 2006. Maize plants infestation by Fusarium spp. in harvest delay conditions (in Polish). Prog. Plant Protection 46: 712-714.

Tekiela A., P. Bereś, J. Grajewski and M. Miklaszewska. 2005. Influence of diseases and pests control on occurrence of fungi on grain and content of mycotoxins (in Polish). Prog. Plant Protection 45: 1149-1152.
Tekiela A. and R. Grabarkiewicz. 2007. Fusrium spp. occurrence and mycotoxin content in grain of genetically modified corn hybrids and traditional maize cultivars in Poland (in Polish). Prog. Plant Protection 47: 227-232.

Tekiela A. 2008. Fusarium spp. occurrence and mycotoxins content in grain of maize cultivars in Wielkopolska and in Podkarpacie (in Polish). Prog. Plant Protection 48: 1121-1125.

Wiśniewska-Dmytrow H. and A. Kozak. 2006. Detection of deoxynivalenol by liquid chromatography (In Polish). $1^{\text {st }}$ ed. National Veterinary Research Institute, Puławy. 